\title{
Introduktion
}

Der tales meget om at reformere den offentlige sektor, men gennemgribende offentlige reformer er i realiteten en sjældenhed. Kommunalreformen fra 2007 er i den forbindelse en undtagelse, der for alvor fordelte opgaver og grænser i den offentlige sektor på ny. 271 kommuner blev til 98, og en lang række opgaver blev flyttet mellem staten, det tidligere amtslige niveau og kommunerne. En sådan reform rejser selvfølgelig en lang række spørgsmål, som forskere med interesse i politik gerne vil besvare. I dette temanummer ser vi nærmere på strukturdelen af Kommunalreformen, dvs. den del, der vedrører kommunernes ændrede grænser og størrelse. Med dette afsæt ser temanummeret på, hvad de mulige konsekvenser af strukturdelen har været for borgernes deltagelse i det lokale demokrati, kommunalpolitikernes hverdag og motivation samt forandringer i den førte politik og organisering i kommunerne. Fælles for artiklerne er derfor, at de har den samme uafhængige variabel, nemlig sammenlægningen af kommunerne, hvis mulige betydning bliver afdækket i en række kvantitative, empiriske studier.

Kommunerne er vigtige i Danmark, de forvalter omkring halvdelen af det offentlige budget og står for størstedelen af den kontakt som borgerne har med „det offentlige“. Derfor er det ikke helt ligegyldigt, hvad kommunerne foretager sig, og hvordan de udvikler sig. På den ene side er der et effektivitetshensyn, et hensyn, der blev fremført meget stærkt i aftalen om Strukturreformen. På den anden side er det et hensyn til det lokale demokrati. Som Anker Brink Lund og Peter Maskell spurgte i deres indledning til et Politika-temanummer ti år efter Kommunalreformen 1970: „er det kommunale selvstyre andet end et ideologisk dogme her ved indgangen til 1980'erne?" Det var en anden reform, men mange af spørgsmålene er de samme. Vi vover pelsen og laver allerede nu en foreløbig evaluering af Kommunalreformen 2007.
I temanummerets første artikel stiller Yosef Bhatti og Kasper Møller Hansen skarpt på kommunesammenlægningernes betydning for valgdeltagelsen ved kommunalvalgene. Forfatterne tager afsæt i det betydelige fald i valgdeltagelsen fra 2005 til 2009 og spørger, om kommunesammenlægningernes nye storkommuner kan bære en del af skylden. Analyserne bygger bl.a. på et unikt datamateriale med flere millioner danske vælgere. Resultatet peger i forskellige retninger, men tilbage står, at kommunesammenlægninger ikke alene kan tilskrives hele skylden for den faldende valgdeltagelse.

Efterfølgende undersøger Jens Olav Dahlgaard og Lene Holm Pedersen kommunesammenlægningernes betydning for kommunalpolitikeres motivation med udgangspunkt i litteraturen om Public Service Motivation (PSM). Forfatterne viser, at kommunalpolitikerne generelt er ens motiverede til 'at gøre godt' for hele samfundet uanset om kommunen er sammenlagt eller ej. Til gengæld kan noget tyde på, at sammenlægningerne kan have påvirket de folkevalgtes brugerorientering. I hvert fald er kommunalpolitikere, der har oplevet de største sammenlægninger i forbindelse med reformen, også de mindst motiverede til at 'gøre godt' for den enkelte borger.

Med den næste artikel kigger Martin Bækgaard nærmere på kommunesammenlægningernes betydning for folkeskolelukninger. Selvom rationalet bag reformen var, at der kunne opnås stordriftsfordele gennem skolelukninger i de nye kommuner, har dette langt fra været tilfældet. Forfatteren argumenterer for, at kommunesammenlægningerne har dannet baggrund for en ny geografisk skillelinje i kommunalpolitik, som på kort sigt har begrænset antallet af skolelukninger i de nye kommuner.

I temasektionens afsluttende artikel runder Asmus Leth Olsen af med en præsentation og diskussion af den øvrige forskning om kommunesammenlægninger- 
nes konsekvenser. Forfatteren udlægger, hvordan eksisterende studier har vist, at kommunalpolitikernes rolle, borgernes lokaldemokratiske opfattelse og kommunernes administrative organisering i varierende omfang er blevet præget af kommunesammenlægningerne. Artiklen afslutter med at argumentere for, hvilke centrale spørgsmål vi stadig mangler at få besvaret med hensyn til kommunesammenlægningernes konsekvenser. Konklusionen er klar: Der er stadig meget, vi ikke ved nok om.

Uden for tema, bringer vi en artikel af Rasmus Brun Pedersen, der ser nærmere på regeringsautonomi og delegeringstab, når danske præferencer i EU traktatforhandlinger fastsættes. Med udgangspunkt i principal-agent teori analyseres det danske forhandlingsmandat i forbindelse med forhandlingen af Maastricht Traktaten, og det sammenlignes med forhandlingernes outcome. Analysen tegner et billede af, at regeringer har et vist råderum til at udnytte forhandlingerne til at realisere resultater, der ligger tættere på deres egne præferencer, men at Folketingets partier ligeledes har muligheder for at udøve uforholdsmæssig stor indflydelse på enkelte delområder.

Nummerets sidste artikel er skrevet af Ali RahighAghsan. Artiklen sætter spørgsmålstegn ved konventionelle beskrivelser af Iran som en voksende magtfaktor, der truer både den regionale og den globale sikkerhed. Artiklen gennemgår påstande om, hvorfor Iran bør ses som en trussel og konkluderer, at både Irans hårde og bløde magt er overvurderet. Der er langt fra grund til panik; Iran kan balanceres.

Som altid afsluttes nummeret med en række boganmeldelser af den nyeste politologiske og samfundsvidenskabelig litteratur.

\section{God læselyst!}

Caroline Howard Grøn og Asmus Leth Olsen Temanummerredaktører 